Covino, K. M., S. R. Morris, M. Shieldcastle, and P. D. Taylor. 2020. Spring migration of Blackpoll Warblers across North America. Avian

Conservation and Ecology 15(1):17. https://doi.org/10.5751/ACE-01577-150117

Copyright $(\mathcal{2} 2020$ by the author(s). Published here under license by the Resilience Alliance.

Research Paper

\title{
Spring migration of Blackpoll Warblers across North America
}

\author{
Kristen M. Covino ${ }^{1,2,3,4}$, Sara R. Morris ${ }^{2,3,4,5}$, Mark Shieldcastle ${ }^{6}$ and Philip D. Taylor ${ }^{7}$ \\ ${ }^{1}$ Biology Department, Loyola Marymount University, Los Angeles, California, USA, ${ }^{2}$ Appledore Island Migration Station, \\ Portsmouth, New Hampshire, USA, ${ }^{3}$ Shoals Marine Laboratory, University of New Hampshire, Durham, New Hampshire, USA, \\ ${ }^{4}$ Braddock Bay Bird Observatory, Hilton, New York, USA, ${ }^{5}$ Canisius College, Buffalo, New York, USA, ${ }^{6}$ Black Swamp Bird \\ Observatory, Oak Harbor, Ohio, USA, ${ }^{7}$ Department of Biology, Acadia University, Wolfville, Nova Scotia, Canada
}

\begin{abstract}
The awe-inspiring seasonal migrations of birds between breeding and wintering grounds has long attracted the interest of casual naturalists and professional ornithologists alike. Although new technologies improve our ability to follow individual migrants throughout their annual cycle, the scale and detail provided by banding records remain incredibly valuable. The focus of avian migration studies is often the most physiologically challenging migratory feats that sometimes leaves certain species or seasons relatively understudied. The Blackpoll Warbler (Setophaga striata) is well-known for its transoceanic migratory flight during fall migration, the season in which it is best studied, yet the details of its spring migration are not well known, at least not at a continental scale. Here we use spring migration banding data on over 15,000 Blackpoll Warblers from 28 banding sites across North America to describe the details of the spring migration patterns in this species. Our data, which spans almost 60 years, indicates that Blackpoll Warblers are migrating earlier at a rate of 0.5 days per decade. We also demonstrate an expected protandrous migratory pattern and an unexpected sex-dependent difference in migration speed with females migrating more quickly than males. Our analyses of longitudinal timing patterns reveal that passage through sites west of $85^{\circ}$ occurs prior to passage at sites east of $85^{\circ}$ and that this difference increases throughout the migratory period, indicating that birds using western sites are migrating faster. Additionally, we provide evidence vis-à-vis analyses of wing length that birds from eastern and western breeding locations mix at lower-latitude migratory sites but their migratory paths diverge as birds proceed north. These results indicate that birds migrating to western breeding sites differ in their migration speed and route thus compensating for the longer migratory distances traveled by western populations of Blackpoll Warblers compared to those breeding in eastern North America.
\end{abstract}

\section{Migration printanière de la Paruline rayée en Amérique du Nord}

RÉSUMÉ. Les migrations saisonnières combien admirables des oiseaux entre leurs aires de nidification et d'hivernage ont depuis longtemps attiré l'attention des naturalistes occasionnels tout comme des ornithologues professionnels. Même si de nouvelles technologies ont permis d'améliorer notre capacité à suivre individuellement les oiseaux migrateurs tout au long de leur cycle annuel, l'échelle et les détails fournis par les retours de bagues ont toujours une très grande valeur. Les études sur les migrations aviaires portent souvent sur l'incroyable défi physiologique qu'elles représentent, ce qui entraine parfois un relatif sous-examen de certaines espèces ou saisons. La Paruline rayée (Setophaga striata) est bien connue pour sa migration transocéanique durant l'automne, saison à laquelle elle est le plus étudiée, mais les détails de sa migration printanière sont peu connus, du moins à l'échelle continentale. Nous avons utilisé les données de baguage réalisé en migration printanière de plus de 15000 Parulines rayées à 28 sites de baguage en Amérique du Nord pour décrire les tendances de la migration printanière de cette espèce. Nos données, qui s'étendaient sur presque 60 ans, ont indiqué que les Parulines rayées migrent plus tôt au rythme de 0,5 jour par décennie. Nous avons aussi observé un profil de migration protandre, auquel nous nous attendions, et une différence dépendante du sexe inattendue sur le plan de la vitesse de migration, les femelles migrant plus rapidement que les mâles. Nos analyses de la tendance de chronologie longitudinale ont révélé que le passage dans les sites à l'ouest du $85^{\circ}$ se produisait avant le passage aux sites à l'est du $85^{\circ}$, et que cette différence augmentait durant la période de migration, indiquant que les oiseaux utilisant les sites dans l'ouest migrent plus rapidement que ceux dans l'est. De plus, nous avons obtenu des indices à partir d'analyses de longueur d'ailes indiquant que les oiseaux provenant des sites de nidification dans l'est et l'ouest se côtoient sur les sites migratoires à des latitudes plus faibles, mais que leur corridors de migration se séparent à mesure qu'ils progressent vers le nord. Ces résultats montrent que les oiseaux qui migrent vers des sites de nidification dans l'ouest ont des vitesses et des trajectoires de migration différentes qui compensent pour les distances de migration plus longues des populations de l'ouest de Parulines rayées comparativement aux oiseaux qui nichent dans l'est de l'Amérique du Nord.

Key Words: banding data; Blackpoll Warbler; phenology; Setophaga striata; spring migration; songbirds 


\section{INTRODUCTION}

Blackpoll Warblers (Setophaga striata) are a quintessential Nearctic-Neotropical migrant that breeds throughout the boreal forests across North America and winters in South America (DeLuca et al. 2013). They are best known for their extraordinary fall migration in which they fly nonstop across the western North Atlantic (Nisbet 1970, Williams and Williams 1978, DeLuca et al. 2015). Blackpoll Warblers follow a different migratory route during spring (loop migrants; DeLuca et al. 2013, Holberton et al. 2015) but even in this season they must also traverse open water including the Caribbean Sea, the Gulf of Mexico, the Great Lakes, and the Gulf of St. Lawrence. As with other migrants, these route differences, coupled with differences in biotic and abiotic factors between seasons, mean that a full understanding of the annual life cycles requires studies of both migratory seasons.

Studies of spring migration patterns in Blackpoll Warblers are limited and have tended to focus on timing. Blackpoll Warbler migration in North America begins in mid-April, where at least some individuals arrive in Florida, apparently from the Antilles or South America (DeLuca et al. 2013, Holberton et al. 2015). Males arrive on breeding grounds earlier than females, with the earliest males arriving by mid-May in Vermont, New Hampshire, and New Brunswick and early June in Alaska (Eliason 1986, DeLuca et al. 2013). Additionally in a small study of 45 birds, Francis and Cooke (1986) found that males arrived slightly before females at a migratory stopover site in Ontario, although this difference was not significant. Measures of mass change during spring migration are limited; trends suggest that Blackpoll Warblers are gaining mass during stopovers in New York and Ontario, but rates vary and are statistically inconclusive (Dunn 2002, Bonter et al. 2007). Additionally, Holzschuh and Deutschlander (2016) showed that spring Blackpoll Warblers had a strong positive relationship between energetic condition and passage date in New York.

Blackpoll Warblers are an excellent model species to explore strategies during spring migration because of their extensive breeding range spanning the continent in the boreal forest, their long-distance migration, and their clear sexual dichromatism. As a result of their breeding range, the distance traveled from their South American wintering grounds by Blackpoll Warblers breeding furthest west is twice that of those breeding in the eastern parts of their range (Morris et al. 2016, DeLuca et al. 2019). Despite these potentially interesting differences in migration patterns across the range of this species, the majority of studies have focused on a single site (e.g., Morris et al. 1994, Dunn 2002, Bonter et al. 2007, Holzschuh and Deutschlander 2016) until recently (DeLuca et al. 2019).

Rosenberg et al. (2016) have suggested that Blackpoll Warbler populations are declining at one of the highest rates of all North American birds. This observation, coupled with the fact that the species has such a broad geographic range (stretching across the entire boreal part of North America, from Newfoundland to Alaska) means that if we can improve our understanding of where and when the birds are migrating; when, if, and where they are stopping over to refuel for migratory flights; and how these differ across the range, we may be able to obtain insights into the species' biology that will be valuable for conservation action or further research.
Our study brings together multiple years of banding data to describe patterns of spring migration of Blackpoll Warblers through North America and to test specific hypotheses about those patterns. Because birds breeding in western locations must travel further during migration than birds breeding in eastern locations, we expected to see differences in data from migratory banding sites across the geographic range. First, we expected to detect differences in timing patterns between the eastern and western migration sites. Second, given the known relationship between migration distance and wing morphology (e.g., Mönkkönen 1995, Lockwood et al. 1998, Vágási et al. 2016), we expected wing length data from eastern and western banding sites in North America to reflect different migration patterns. Third, we expected to see differences in energetic condition between birds captured at eastern and western sites. Additionally, given that male Blackpoll Warblers arrive at breeding grounds earlier than females (DeLuca et al. 2013), we expected that this protandry will be reflected in the timing of passage between males and females. Finally, we hypothesized that, given Blackpoll Warblers typically migrate later than most other parulid migrants (Rodewald 2015), we would not see biologically meaningful changes in migration phenology across years.

\section{METHODS}

We used spring banding data on Blackpoll Warblers from 28 sites collected between 1960 and 2017 (Table 1, Fig. 1). All Blackpoll Warbler banding data were requested from the U.S. Geological

Fig. 1. Location of banding sites included in this study of Blackpoll Warbler (Setophaga striata) spring migration. We used data from 28 sites that are listed in Table 1. Open circles indicate the location of these sites, and the size of each circle represents that average number of Blackpolls banded per year. Color indicates whether sites were east (orange) or west (purple) of the $85^{\circ}$ longitude line. The gray shaded area represents the breeding range of the Blackpoll Warbler (Retrieved from the USGS ScienceBase-Catalog; https://www. sciencebase.gov/catalog/item/59f5ec3fe4b063d5d307e55f)

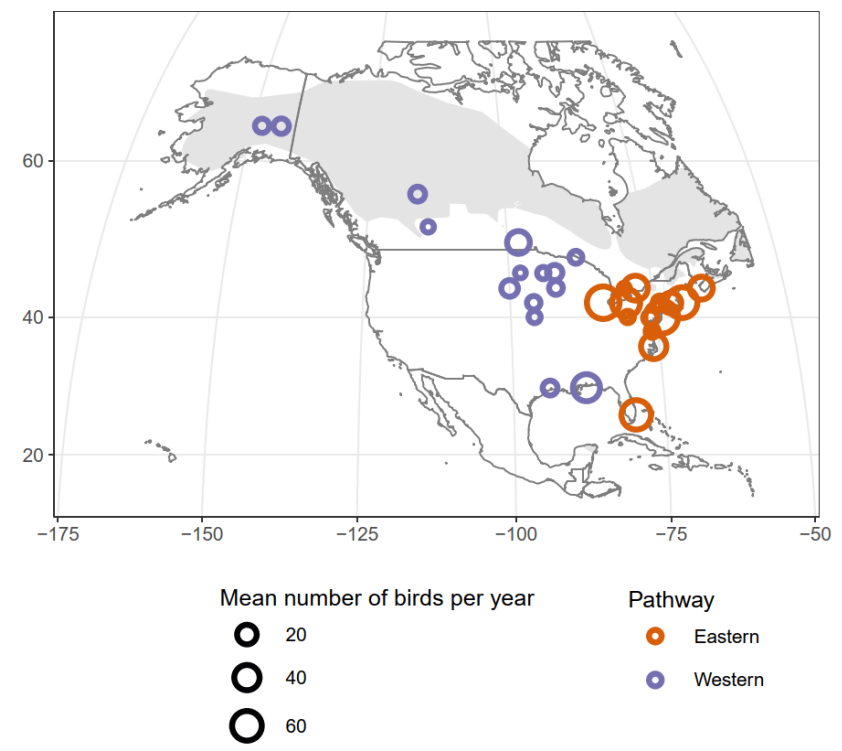


Table 1. Locations and dates of Blackpoll Warbler (Setophaga striata) banding data in this study.

\begin{tabular}{|c|c|c|c|c|c|c|c|c|}
\hline Banding site & Code & Lat-long & $\begin{array}{l}\text { Range of } \\
\text { years }\end{array}$ & $\begin{array}{c}\text { Overall } \\
\text { date of } \\
\text { early } \\
\text { capture }\end{array}$ & $\begin{array}{l}\text { Median } \\
\text { date of } \\
\text { early } \\
\text { capture }^{\S}\end{array}$ & $\begin{array}{l}\text { Overall } \\
\text { median } \\
\text { date of } \\
\text { capture }\end{array}$ & $\begin{array}{l}\text { Median } \\
\text { date of } \\
\text { late } \\
\text { capture }\end{array}$ & $\begin{array}{c}\text { Overall } \\
\text { date of late } \\
\text { capture }^{\#}\end{array}$ \\
\hline Alaska Bird Observatory, Alaska & ALAS & $64^{\circ} \mathrm{N}, 146^{\circ} \mathrm{W}$ & 1992-2012 & 135 & 137 & 145 & 156 & 158 \\
\hline Appledore Island Migration Station, Maine & AIMS & $42^{\circ} \mathrm{N}, 70^{\circ} \mathrm{W}$ & $1990-2015$ & 130 & 131 & 148 & 160 & 161 \\
\hline Atlantic Bird Observatory, Nova Scotia & $\mathrm{ABO}$ & $44^{\circ} \mathrm{N}, 66^{\circ} \mathrm{W}$ & 1996-2006 & 133 & 134 & 145 & 154 & 156 \\
\hline $\begin{array}{l}\text { Bernard Fashingbauer Banding Operations, } \\
\text { Wisconsin }\end{array}$ & BFBO & $44^{\circ} \mathrm{N}, 92^{\circ} \mathrm{W}$ & 1996-2014 & 126 & 126 & 139 & 144 & 145 \\
\hline Birdsville, Maryland & BIMD & $38^{\circ} \mathrm{N}, 76^{\circ} \mathrm{W}$ & 1981-2014 & 125 & 131 & 140 & 147 & 147 \\
\hline Black Swamp Bird Observatory, Ohio & BSBO & $42^{\circ} \mathrm{N}, 84^{\circ} \mathrm{W}$ & 1992-2015 & 121 & 124 & 141 & 156 & 157 \\
\hline Block Island, Rhode Island & BI & $42^{\circ} \mathrm{N}, 72^{\circ} \mathrm{W}$ & 1967-2009 & 131 & 134 & 144 & 154 & 162 \\
\hline Braddock Bay Bird Observatory, New York & $\mathrm{BBBO}$ & $44^{\circ} \mathrm{N}, 78^{\circ} \mathrm{W}$ & 1992-2015 & 135 & 137 & 148 & 157 & 158 \\
\hline Cape Florida Banding Station, Florida & CFBS & $26^{\circ} \mathrm{N}, 80^{\circ} \mathrm{W}$ & $2007-2014$ & 109 & 109 & 124 & 137 & 137 \\
\hline Delta Marsh Bird Observatory, Manitoba & DEMA & $50^{\circ} \mathrm{N}, 98^{\circ} \mathrm{W}$ & 1995-2009 & 130 & 133 & 146 & 155 & 155 \\
\hline First Landing State Park, Virginia & FLSP & $36^{\circ} \mathrm{N}, 76^{\circ} \mathrm{W}$ & 2005-2012 & 121 & 122 & 135 & 150 & 150 \\
\hline $\begin{array}{l}\text { Foreman's Branch Bird Observatory, } \\
\text { Maryland }\end{array}$ & FBBO & $40^{\circ} \mathrm{N}, 76^{\circ} \mathrm{W}$ & 1997-2014 & 128 & 128 & 139 & 149 & 150 \\
\hline Great Gull Island, New York & GGI & $42^{\circ} \mathrm{N}, 72^{\circ} \mathrm{W}$ & $1971-1983$ & 128 & 130 & 144 & 161 & 162 \\
\hline Island Beach State Park, New Jersey & IBSP & $40^{\circ} \mathrm{N}, 74^{\circ} \mathrm{W}$ & $2008-2014$ & 127 & 127 & 137 & 143 & 144 \\
\hline Lesser Slave Lake Bird Observatory, Alberta & LSL & $56^{\circ} \mathrm{N}, 116^{\circ} \mathrm{W}$ & 1995-2012 & 130 & 131 & 141 & 154 & 156 \\
\hline Long Point Bird Observatory, Ontario & LPBO & $42^{\circ} \mathrm{N}, 80^{\circ} \mathrm{W}$ & $1990-2013$ & 133 & 135 & 148 & 160 & 161 \\
\hline Louisiana Gulf Coast, Louisiana & LGC & $30^{\circ} \mathrm{N}, 94^{\circ} \mathrm{W}$ & 1988-2013 & 105 & 110 & 117 & 129 & 137 \\
\hline Manomet Bird Observatory, Massachusetts & $\mathrm{MBO}$ & $42^{\circ} \mathrm{N}, 70^{\circ} \mathrm{W}$ & 1969-2015 & 131 & 134 & 146 & 164 & 166 \\
\hline Mississippi Barrier Islands, Mississippi & MBI & $30^{\circ} \mathrm{N}, 88^{\circ} \mathrm{W}$ & 1987-1994 & 101 & 103 & 119 & 131 & 132 \\
\hline $\begin{array}{l}\text { Patuxent Wildlife Research Center Migration } \\
\text { Station, Maryland }\end{array}$ & PWRC & $40^{\circ} \mathrm{N}, 77^{\circ} \mathrm{W}$ & $1966-2014$ & 132 & 136 & 144 & 151 & 151 \\
\hline $\begin{array}{l}\text { Potomac River National Wildlife Refuge, } \\
\text { Virginia }\end{array}$ & PRNWR & $42^{\circ} \mathrm{N}, 70^{\circ} \mathrm{W}$ & $1998-2105$ & 132 & 134 & 146 & 152 & 154 \\
\hline Powdermill Bird Observatory, Pennsylvania & PARC & $40^{\circ} \mathrm{N}, 80^{\circ} \mathrm{W}$ & 1966-2016 & 130 & 134 & 142 & 153 & 158 \\
\hline Presque Isle State Park, Pennsylvania & PISP & $42^{\circ} \mathrm{N}, 80^{\circ} \mathrm{W}$ & $2008-2015$ & 133 & 135 & 146 & 149 & 150 \\
\hline Seaside Park, New Jersey & SPNJ & $40^{\circ} \mathrm{N}, 74^{\circ} \mathrm{W}$ & 1960-2014 & 129 & 130 & 142 & 155 & 163 \\
\hline $\begin{array}{l}\text { South Dakota Game, Fish, and Parks, South } \\
\text { Dakota }\end{array}$ & SDGF & $44^{\circ} \mathrm{N}, 100^{\circ} \mathrm{W}$ & $1992-2015$ & 127 & 129 & 139 & 151 & 157 \\
\hline Thunder Cape Bird Observatory, Ontario & TCBO & $48^{\circ} \mathrm{N}, 88^{\circ} \mathrm{W}$ & 1992-2013 & 136 & 137 & 147 & 157 & 158 \\
\hline Upstate New York & USNY & $40^{\circ} \mathrm{N}, 74^{\circ} \mathrm{W}$ & 1967-2013 & 132 & 132 & 140 & 147 & 147 \\
\hline
\end{tabular}

${ }^{\dagger}$ First and last year of banding data included in this study.

† The overall date of early capture is the earliest date by which $5 \%$ of individuals in any year had been captured (q5).

${ }^{\S}$ The median date of early capture is the median across years of q5, the date by which $5 \%$ of individuals in any year had been captured.

'Median date of all captures was calculated by taking the median of each year's median date of capture.

"The median date of late capture is the median across years of q95, the date by which $95 \%$ of individuals in any year had been captured.

${ }^{\#}$ The overall date of late capture is the latest date by which $95 \%$ of individuals in any year had been captured (q95).

Survey (USGS) Bird Banding Laboratory and a site was included in this study if it had at least 40 captures of Blackpoll Warblers across the entire time period (1960-2017). The years from which we obtained data, and the sample sizes, varied considerably among stations (Table 1). Station protocols varied (including hours of operation) but all used mist nets for capture, which were usually opened by dawn and remained open for at least $6 \mathrm{~h}$, weather permitting. We also requested full banding data from as many of the sites identified by the USGS dataset as possible, which allowed for a more complete set of data on Blackpoll Warblers (e.g., USGS data often lacks wing chord and mass). From data sets supplied by individual sites we extracted information on age, sex, wing chord, and mass for each individual. Age and sex determination was based on plumage characteristics described in the North American Bird Banding Manual (United States Fish and Wildlife Service and Canadian Wildlife Service 1977) or other related publications (Wood 1969, Pyle et al. 1987, Pyle 1997). We removed records where sex could not be determined, which accounted for $2.6 \%$ of our original dataset and varied among stations from 0 to $15 \%$ (Table 2). Additionally, we excluded data on recaptured birds.

We further excluded some data from individual analyses when necessary to avoid bias. We did not analyze age because the proportion of birds that were aged to a specific age category ("second-year" or "after-second-year" compared to the less specific "after-hatch-year") varied considerably among stations. We also excluded individuals from analyses involving wing length or mass where those measures were missing (20.2\% and $28.7 \%$ of individuals, respectively).

\section{Data processing and approach}

To assess the hypotheses outlined above, we examined how migration timing, wing length, and energetic condition (mass with wing length as a covariate; e.g., Morris et al. 2016) varied with sex, geographic location of the stations, and the great circle distance from overwintering grounds (Morris et al. 2016). In 
Table 2. Sample sizes, sex ratios, wing chord lengths, and mass data of Blackpoll Warblers (Setophaga striata) used in this study.

\begin{tabular}{|c|c|c|c|c|c|c|c|c|c|}
\hline Banding site & $\mathrm{n}^{\dagger}$ & $\begin{array}{l}\text { Unknown } \\
\operatorname{sex}(\%)^{*}\end{array}$ & $\begin{array}{l}\text { Male } \\
(\%)^{\S}\end{array}$ & $\begin{array}{c}\text { Male } \\
\text { Median } \\
\text { Capture } \\
\text { Date }\end{array}$ & $\begin{array}{l}\text { Female } \\
\text { Median } \\
\text { Capture } \\
\text { Date }\end{array}$ & $\begin{array}{l}\text { Male wing } \\
\text { chord }(\mathrm{mm}) \mid\end{array}$ & $\begin{array}{l}\text { Female wing } \\
\text { chord }(\mathrm{mm}) \mid\end{array}$ & $\begin{array}{l}\text { Male mass } \\
(\mathrm{g})^{\uparrow}\end{array}$ & $\begin{array}{l}\text { Female mass } \\
(\mathrm{g})^{\boldsymbol{q}}\end{array}$ \\
\hline Alaska Bird Observatory, Alaska & 195 & 3.1 & 61.9 & 144 & 146 & $75.9 \pm 2.1$ & $71.9 \pm 1.7$ & $12.9 \pm 0.8$ & $11.8 \pm 0.7$ \\
\hline $\begin{array}{l}\text { Appledore Island Migration Station, } \\
\text { Maine }\end{array}$ & 1898 & 0.3 & 42.9 & 146 & 150 & $72.6 \pm 2.0$ & $69.2 \pm 1.9$ & $14.5 \pm 2.0$ & $13.6 \pm 1.9$ \\
\hline Atlantic Bird Observatory, Nova Scotia & 342 & 0.0 & 66.1 & 144 & 148 & $72.5 \pm 2.1$ & $68.9 \pm 1.9$ & $14.0 \pm 2.0$ & $13.3 \pm 1.6$ \\
\hline $\begin{array}{l}\text { Bernard Fashingbauer Banding } \\
\text { Operations, Wisconsin }\end{array}$ & 66 & 0.0 & 69.7 & 137 & 138 & $74.5 \pm 1.9$ & $70.6 \pm 1.3$ & NA & NA \\
\hline Birdsville, Maryland & 121 & 7.4 & 58.0 & 131 & 135 & $71.9 \pm 2.3$ & $68.8 \pm 2.0$ & NA & NA \\
\hline Black Swamp Bird Observatory, Ohio & 1822 & 0.0 & 53.1 & 139 & 143 & $72.4 \pm 2.1$ & $69.0 \pm 1.8$ & $13.9 \pm 2.0$ & $13.1 \pm 1.7$ \\
\hline Block Island, Rhode Island & 898 & 3.2 & 50.9 & 143 & 146 & $72.3 \pm 2.0$ & $68.6 \pm 1.9$ & $15.3 \pm 1.8$ & $14.1 \pm 1.8$ \\
\hline $\begin{array}{l}\text { Braddock Bay Bird Observatory, New } \\
\text { York }\end{array}$ & 1014 & 9.7 & 48.5 & 144 & 149 & $72.7 \pm 2.0$ & $69.0 \pm 2.2$ & $13.4 \pm 1.5$ & $12.6 \pm 1.5$ \\
\hline Cape Florida Banding Station, Florida & 297 & 0.0 & 61.6 & 121 & 126 & $74.3 \pm 2.2$ & $70.7 \pm 1.8$ & $11.8 \pm 1.2$ & $10.8 \pm 1.0$ \\
\hline Delta Marsh Bird Observatory, Manitoba & 456 & 0.7 & 49.9 & 145 & 148 & $74.0 \pm 2.2$ & $70.5 \pm 1.8$ & $14.3 \pm 1.8$ & $13.5 \pm 1.5$ \\
\hline First Landing State Park, Virginia & 321 & 0.0 & 50.5 & 135 & 139 & $71.9 \pm 1.8$ & $68.7 \pm 1.8$ & $12.0 \pm 1.1$ & $11.4 \pm 1.1$ \\
\hline $\begin{array}{l}\text { Foreman's Branch Bird Observatory, } \\
\text { Maryland }\end{array}$ & 129 & 0.8 & 71.9 & 132 & 142 & $73.0 \pm 2.0$ & $69.4 \pm 1.5$ & $12.5 \pm 1.1$ & $12.1 \pm 1.5$ \\
\hline Great Gull Island, New York & 102 & 2.0 & 38.0 & 141 & 147 & $72.1 \pm 2.2$ & $68.8 \pm 2.9$ & $14.8 \pm 2.2$ & $13.9 \pm 2.2$ \\
\hline Island Beach State Park, New Jersey & 74 & 0.0 & 60.8 & 138 & 140 & $74.0 \pm 2.3$ & $70.0 \pm 1.5$ & $13.5 \pm 1.8$ & $12.7 \pm 1.7$ \\
\hline $\begin{array}{l}\text { Lesser Slave Lake Bird Observatory, } \\
\text { Alberta }\end{array}$ & 141 & 2.8 & 64.2 & 139 & 144 & $74.8 \pm 2.1$ & $70.7 \pm 2.1$ & $13.3 \pm 1.4$ & $12.0 \pm 0.9$ \\
\hline Long Point Bird Observatory, Ontario & 1147 & 0.8 & 50.4 & 144 & 150 & $72.7 \pm 2.2$ & $69.4 \pm 2.0$ & $13.4 \pm 1.7$ & $12.9 \pm 1.7$ \\
\hline Louisiana Gulf Coast, Louisiana & 206 & 8.7 & 73.4 & 116 & 118 & $74.6 \pm 2.0$ & $71.5 \pm 1.9$ & $11.6 \pm 1.6$ & $10.7 \pm 1.2$ \\
\hline $\begin{array}{l}\text { Manomet Bird Observatory, } \\
\text { Massachusetts }\end{array}$ & 1188 & 8.6 & 42.8 & 144 & 150 & $71.9 \pm 2.0$ & $68.4 \pm 1.8$ & $15.4 \pm 2.1$ & $14.4 \pm 1.8$ \\
\hline Mississippi Barrier Islands, Mississippi & 449 & 15.1 & 72.2 & 117 & 122 & $74.7 \pm 2.1$ & $71.3 \pm 2.6$ & $10.1 \pm 0.8$ & $9.5 \pm 1.0$ \\
\hline $\begin{array}{l}\text { Patuxent Wildlife Research Center } \\
\text { Migration Station, Maryland }\end{array}$ & 344 & 2.0 & 56.7 & 142 & 143 & NA & NA & NA & NA \\
\hline $\begin{array}{l}\text { Potomac River National Wildlife Refuge, } \\
\text { Virginia }\end{array}$ & 133 & 0.0 & 33.8 & 146 & 148 & $73.3 \pm 2.1$ & $69.4 \pm 1.6$ & $15.0 \pm 2.1$ & $13.9 \pm 1.7$ \\
\hline $\begin{array}{l}\text { Powdermill Bird Observatory, } \\
\text { Pennsylvania }\end{array}$ & 180 & 1.7 & 64.4 & 141 & 145 & $73.8 \pm 1.8$ & $70.2 \pm 1.7$ & $13.0 \pm 1.5$ & $12.2 \pm 1.3$ \\
\hline Presque Isle State Park, Pennsylvania & 234 & 0.0 & 50.4 & 146 & 146 & $73.0 \pm 1.9$ & $69.5 \pm 1.8$ & $13.7 \pm 1.6$ & $13.1 \pm 1.5$ \\
\hline Seaside Park, New Jersey & 4127 & 4.7 & 50.0 & 141 & 144 & $72.7 \pm 1.9$ & $69.2 \pm 1.7$ & $13.6 \pm 2.0$ & $12.6 \pm 1.6$ \\
\hline $\begin{array}{l}\text { South Dakota Game, Fish, and Parks, } \\
\text { South Dakota }\end{array}$ & 261 & 0.8 & 55.6 & 138 & 142 & $74.9 \pm 2.2$ & $71.4 \pm 1.9$ & $15.0 \pm 1.9$ & $13.8 \pm 1.7$ \\
\hline Thunder Cape Bird Observatory, Ontario & 94 & 1.1 & 51.6 & 143 & 147 & $73.7 \pm 2.2$ & $70.1 \pm 2.0$ & $12.5 \pm 1.5$ & $12.1 \pm 1.4$ \\
\hline Upstate New York & 286 & 0.8 & 63.4 & 140 & 140 & $73.4 \pm 2.0$ & $69.9 \pm 1.6$ & $14.0 \pm 1.7$ & $12.3 \pm 1.3$ \\
\hline
\end{tabular}

Sample sizes reflect all birds captured during the scope of this study.

"Percent of birds captured that were of unknown sex. These birds were excluded from all analyses.

${ }^{\S}$ Percentage of known sex birds that were designated as male.

We present mean and standard deviation for wing chord and mass.

${ }^{9}$ Lean birds were those with fat scores of 0 or 1 on our 5-point scale (referring to no fat or a trace of fat).

addition, we considered possible effects of year in models investigating migration phenology.

In analyses investigating differences in migration patterns across the range, we considered "pathway," i.e., whether a station was "eastern" (east of $85^{\circ}$ ) or "western" (west of $85^{\circ}$ longitude). We chose $85^{\circ}$ because it separates the Florida peninsula from the Gulf of Mexico, and the eastern Great Lakes (Huron, Erie, Ontario) from the Western Great Lakes (Superior and Michigan). That longitudinal break also loosely coincides with the natural break in the species' population distribution caused by the southward projection of James Bay into Northern Ontario and Quebec (Fig. 1). More recent research (DeLuca et al. 2019) suggests that during spring migration, western birds stop over in an area southwest of the Great Lakes, which adds additional credence to using this specific longitude as a dividing line. Although precise overwinter locations of individuals from eastern and western populations are unknown, as in Morris et al. (2016) we calculated the great circle distance from the location to a central point in the wintering grounds (lat/long $\left.=1^{\circ} \mathrm{N}, 66^{\circ} \mathrm{W}\right)$.

We directly assessed migration timing by examining the relationship between early, middle, and late migrants and our predictors of interest. Early migration was defined as the quantile where $5 \%$ of individuals had been observed in a given year and site (e.g., Van Buskirk et al. 2009). Likewise, median migration was the date at which $50 \%$ of the individuals had been observed and late migration was the date at which $95 \%$ of the individuals had been observed. These models allowed us to test hypotheses regarding variation in passage date while limiting the effects of extremely early and extremely late migrants (Morris et al. 2016). 


\section{Models and analysis}

All models were fit as linear mixed effects models using package lme4 in program R (Bates et al. 2014). In models investigating migration timing, each response (early, median, and late migration timing) was fit against three predictors: great circle distance, pathway (a binary variable, east or west of longitude $85^{\circ}$ ), sex, and year (a single term, to measure an overall trend in phenology through time). Year and site were included as separate random effects in all models to account for additional within-year variation across all stations and within-station variation across all years. In models investigating energetic condition, we used mass as the response variable, included wing length as a covariate, and included day of year, great circle distance, sex, and pathway as predictors. We also fit models investigating wing length as a response variable against the predictors of day of year, great circle distance, sex, and pathway.

When graphical analyses suggested a polynomial term (specifically for great circle distance in the timing models and great circle distance and day of year in the mass models) we first compared a simple model (all main effects but no interactions) that included either the term (day of year or great circle distance) to a model with the term squared using a likelihood ratio test. We then subsequently included either the polynomial or not in all additional models. In these polynomial models, we took the square root of the great circle distance (in units of $1000 \mathrm{~s}$ of $\mathrm{km}$ ) to reduce the impact of the four extreme NW locations on the parameter estimates.

For models investigating timing, we used a likelihood ratio approach for model selection. We fit an initial model containing all main effects ("main effect model") and then used it to assess possible additional effects of interactions between the main effects and pathway or year. The effect of each possible interaction was compared to the main effect model using a likelihood ratio test. We then fit a final model that included any interactions that had improved the fit of the simpler, main effect, model.

For mass (energetic condition) and wing-length models, we followed a slightly different approach. We first fit full models including the main effects plus all two-way interactions involving day of year, great circle distance, sex, and pathway. We then used a likelihood ratio test to see if there was evidence for any of the three-way interactions that involved pathway (to test whether any of the two-way interactions differed by pathway).

For all final models we report parameter estimates plus their estimated standard errors, and the results of a t-test indicating whether there was evidence those parameter estimates differed from zero. When reporting on final models, we focus on interpreting the biological effects (e.g. the magnitude and direction of the coefficients) in these models and used plots of raw data to interpret the meaning and relative strength of these higher order effects relative to the main effects. We used Program $\mathrm{R}$ (version 3.1) for all data analyses.

\section{RESULTS}

For migration timing models, we analyzed data from 15,796 new captures from the 28 banding sites (Table 2). Because not all captures included all data, the number of individuals included in mass models was 11,288 and wing length models was 12,717.

\section{Migration timing}

There was no evidence for any two-way interactions involving pathway in the timing models, suggesting a comparable overall migration pace for eastern and western sites and no evidence for differences in pace for the sexes between the two pathways. Migration timing varied with pathway, sex, and distance from the wintering grounds (Table 3). The midpoint of migration (50th quantile) for birds captured at western sites was about $14.8 \pm 1.8$ days earlier than for birds captured at eastern sites, and the midpoint of males preceded females by about $4.1 \pm 0.3$ days (Table 3; Appendix 1). For both eastern and western sites there was a nonlinear relationship between great-circle distance on migratory progression (the timing of early, median, and late migration), which appears to be much more pronounced for western sites (Fig. 2).

Fig. 2. Date of capture of Blackpoll Warblers (Setophaga striata) by sex during spring migration. Sites are separated into eastern and western locations. Points represent a single banding site and color represents the overall median date of early capture (the date by which 5\% of birds were captured annually, q5), the overall median date of capture (q50), and the overall median date of late capture (the date by which $95 \%$ of birds were captured annually, q95).

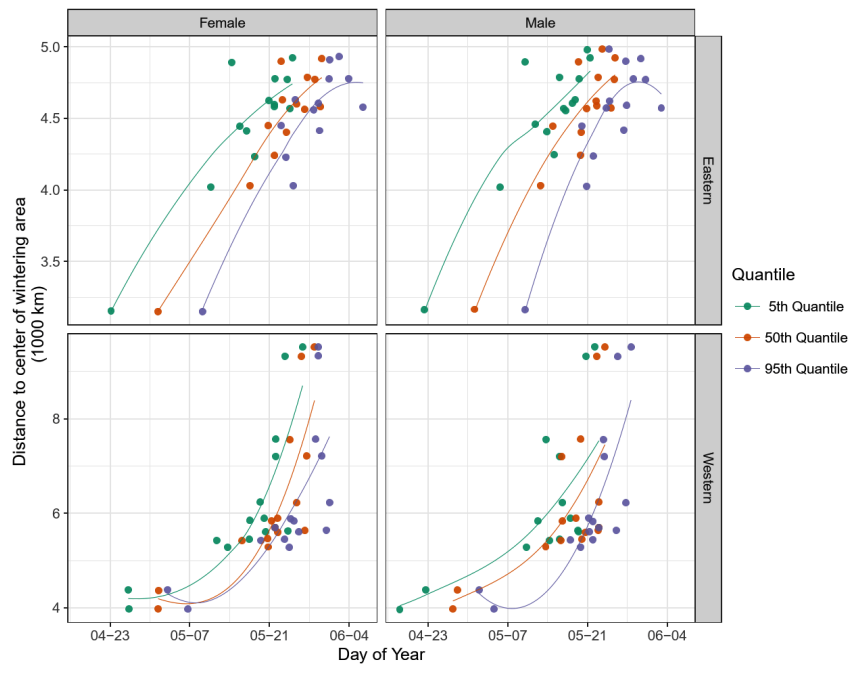

Patterns of early (5th quantile) and late (95th quantile) migration were very similar but demonstrate some interesting patterns (Table 3; Fig. 2). Males consistently preceded females, however, the difference in timing between males and females varied and ultimately decreased slightly (by a little more than 1 day) over the course of migration (comparing early to late migration; Table 3). Migration through western sites occurred earlier than eastern sites and this difference stayed relatively consistent over the course of migration indicating (Table 3; coefficient for pathway). Migration occurred earlier across all three timing quantiles, but the degree of change varied between 0.7 days per decade for early migration and 0.3 days per decade for median migration (Table 3 ; note the overlapping standard errors of these estimates).

We also examined the influence of three southernmost sites on the model fits by refitting the timing models (early, median, and 
Table 3. Variable estimates from the final linear mixed models for early, median, and late passage by Blackpoll Warblers (Setophaga striata) in North America.

\begin{tabular}{llcc}
\hline \hline Model & Variable & Estimate \pm SE & $t$-value \\
\hline Early migration (5th quantile) & Pathway (East vs. West) & $-13.39 \pm 1.72$ & -7.77 \\
& Distance (polynomial 1) & $229.23 \pm 22.29$ & 10.29 \\
& Distance (polynomial 2) & $-125.27 \pm 16.29$ & -7.69 \\
& Sex & $-3.78 \pm 0.28$ & -13.45 \\
& Year & $-0.07 \pm 0.02$ & -3.30 \\
& Year*Distance (polynomial 1) & $-1.05 \pm 0.71$ & -1.48 \\
& Year* Distance (polynomial 2) & $1.62 \pm 0.71$ & 2.29 \\
Median migration (50th quantile) & Pathway (East vs. West) & $-14.77 \pm 1.80$ & -8.22 \\
& Distance (polynomial 1) & $103.54 \pm 9.95$ & 10.41 \\
& Distance (polynomial 2) & $-46.75 \pm 7.67$ & -6.10 \\
& Sex & $-4.10 \pm 0.30$ & -13.64 \\
Late migration (95th quantile) & Year & $-0.03 \pm 0.02$ & -1.45 \\
& Pathway (East vs. West) & $-14.70 \pm 1.77$ & -8.30 \\
& Distance (polynomial 1) & $174.99 \pm 22.26$ & 7.86 \\
& Distance (polynomial 2) & $-74.33 \pm 15.85$ & -4.69 \\
& Sex & $-2.57 \pm 0.28$ & -9.09 \\
\hline
\end{tabular}

late) without those sites. There were only minor differences from the above described models and thus data are presented for the complete models only (those that included the southernmost sites).

\section{Wing length}

There was evidence for all two-way interactions involving pathway in the initial wing length models, but no evidence for any threeway interactions. We therefore fit separate models for birds from eastern and western pathways. At both eastern and western sites, males had longer wings compared to females (approximately 3 $\mathrm{mm}$; Table 4). However, the interactions between model terms differed between eastern and western sites. At western sites there was a greater difference between the sexes in wing length at more distant sites but at eastern sites the difference in wing length between males and females was more pronounced earlier in the migratory season (interaction between sex and day; Table 4). At both eastern and western sites birds with longer wings arrived earlier (Fig. 3); but at eastern sites, that effect varied with sex (Table 4). At western sites, wing lengths of birds captured at the southernmost locations were shorter than those at midlatitude sites by $0.5 \mathrm{~mm}$ and $1-2 \mathrm{~mm}$ shorter than birds arriving on their western breeding grounds, but a similar difference was not observed in the eastern sites (estimate coefficient of western sites is $0.5 \mathrm{~mm} / 1000 \mathrm{~km}$; Table 4).

\section{Energetic condition}

There was evidence for a nonlinear relationship between mass and great circle distance, so great circle distance was included as a second-order polynomial in all models. Further, there was evidence for a three-way interaction involving the effects of great circle distance, day of year, and pathway on mass; that is, the interaction between the effects of day of year on mass differ by great circle distance, but those effects are not the same for each pathway. We therefore split the models into eastern and western subsets.
Fig. 3. Blackpoll Warbler (Setophaga striata) mass (corrected by wing length) by latitudinal and longitudinal bins throughout spring migration. Mass of birds captured at eastern (orange) and western (purple) sites were lowest at the southernmost sites and highest at the midlatitude and more northerly sites.

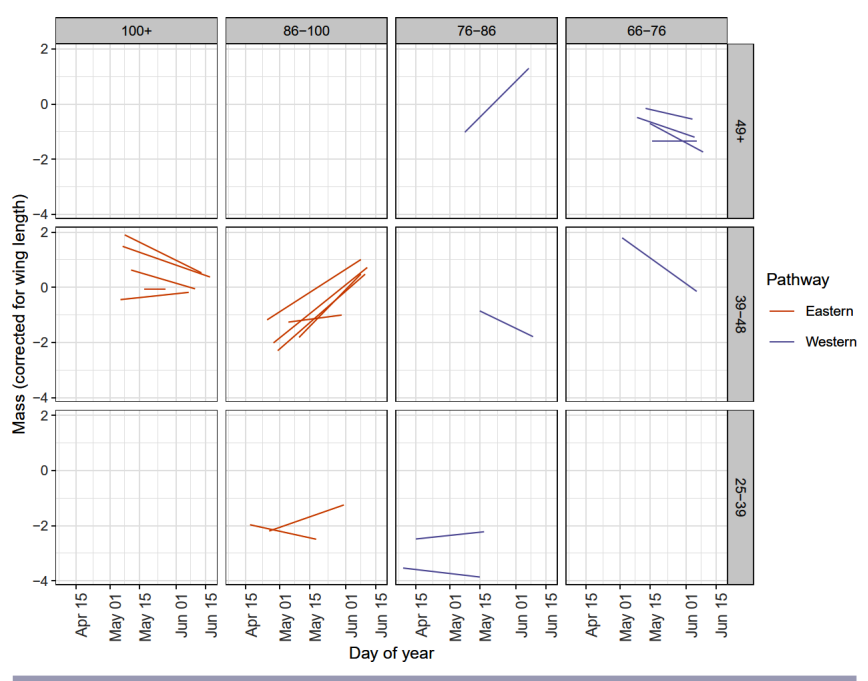

At both eastern and western sites, mass increased with wing length (larger birds have more mass), and after accounting for wing length, males had a higher mass than females (Table 4; Fig. 4). At eastern sites, the effect of great circle distance on mass was nonlinear and that effect varied both with sex and with day of year (Table 4). At both eastern and western sites individuals captured at southern sites along the Gulf of Mexico are below expected mass (standardized for wing length; ' 0 ' in Fig. 4), whereas birds captured at sites in the midwest are above expected mass (Figs. 4 and 5). In addition, at eastern sites, mass is higher over midlatitudes and is near the expected mass near eastern breeding sites while at western sites mass is highest at midlatitudes but lower near the most northern parts of the breeding range (Figs. 4 and 5). 
Table 4. Variable estimates from the final linear mixed models for wing and mass for Blackpoll Warblers (Setophaga striata) in North America. Eastern and western pathways were analyzed separately.

\begin{tabular}{|c|c|c|c|}
\hline Model & Variable & Estimate $\pm \mathrm{SE}$ & $t$-value \\
\hline \multirow[t]{4}{*}{ Wing (Western pathway) } & Distance & $0.52 \pm 0.09$ & 5.83 \\
\hline & Sex & $3.02 \pm 0.14$ & 22.36 \\
\hline & Day & $-0.09 \pm 0.009$ & -10.49 \\
\hline & Sex * Distance & $0.13 \pm 0.06$ & 2.09 \\
\hline \multirow[t]{5}{*}{ Wing (Eastern pathway) } & Distance & $-0.09 \pm 0.40$ & -0.22 \\
\hline & Sex & $3.26 \pm 0.04$ & 81.44 \\
\hline & Day & $-0.06 \pm 0.004$ & -13.34 \\
\hline & Sex * Day & $-0.02 \pm 0.005$ & -3.50 \\
\hline & Distance * Day & $-0.02 \pm 0.008$ & -2.31 \\
\hline \multirow[t]{5}{*}{ Mass (Western pathway) } & Distance (polynomial 1) & $17.09 \pm 8.21$ & 2.08 \\
\hline & Distance (polynomial 2) & $-34.64 \pm 8.37$ & -4.14 \\
\hline & Sex & $0.58 \pm 0.09$ & 6.19 \\
\hline & Day & $0.02 \pm 0.007$ & 3.45 \\
\hline & Wing & $0.11 \pm 0.02$ & 6.09 \\
\hline \multirow[t]{9}{*}{ Mass (Eastern pathway) } & Distance (polynomial 1) & $41.30 \pm 15.43$ & 2.68 \\
\hline & Distance (polynomial 2) & $5.47 \pm 16.93$ & 0.32 \\
\hline & Sex & $0.29 \pm 0.05$ & 6.33 \\
\hline & Day & $0.04 \pm 0.003$ & 11.84 \\
\hline & Wing & $0.21 \pm 0.009$ & 23.47 \\
\hline & Distance (polynomial 1) $*$ Sex & $1.37 \pm 3.53$ & 0.39 \\
\hline & Distance (polynomial 2) $*$ Sex & $-0.43 \pm 3.57$ & -0.12 \\
\hline & Distance (polynomial 1) * Day & $1.92 \pm 0.25$ & 7.58 \\
\hline & Distance (polynomial 2) * Day & $1.80 \pm 0.28$ & 6.46 \\
\hline
\end{tabular}

Fig. 4. Boxplots of mass of Blackpoll Warblers (Setophaga striata) during spring migration. Data from females is shown in the left panel and from males in the right panel. Boxes show the first and third quartile, the bar within the box is the median, the lines above and below the boxes represent the highest and lowest data points that fall within 1.5 standard deviations of the respective quartile range, and individual points fall outside these values. Sites are provided using the latitude-longitude bin of each site (see methods). Western sites are indicated by orange bars and eastern sites are indicated by purple bars.

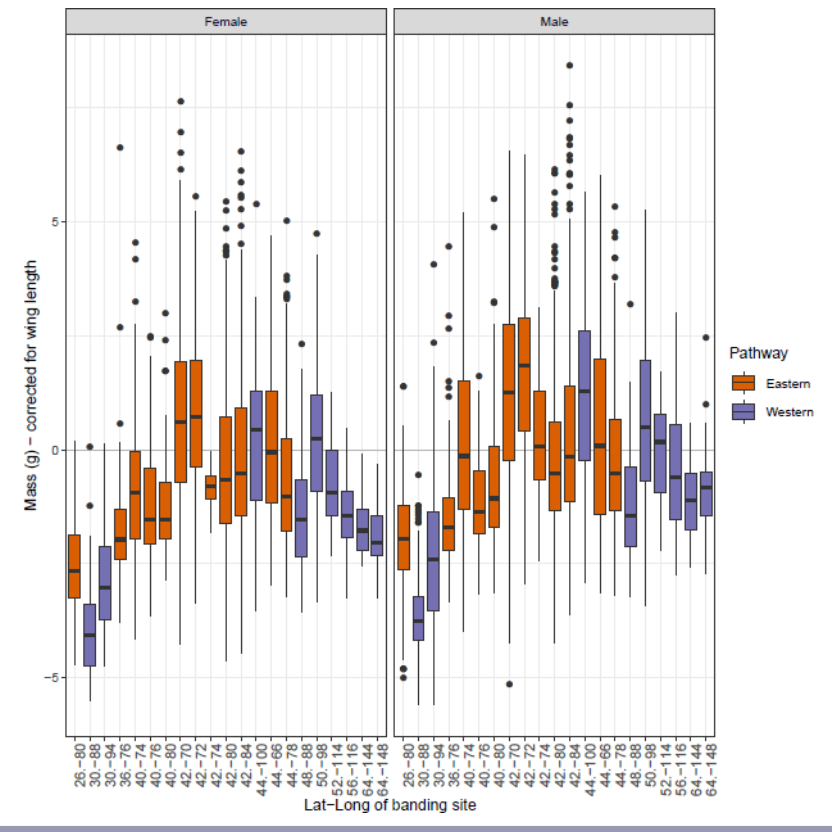

Fig. 5. Blackpoll Warbler (Setophaga striata) mass (corrected by wing length) by sex and latitudinal bin throughout spring migration. For both western (purple) and eastern (orange) sites, masses were higher at higher latitudes.

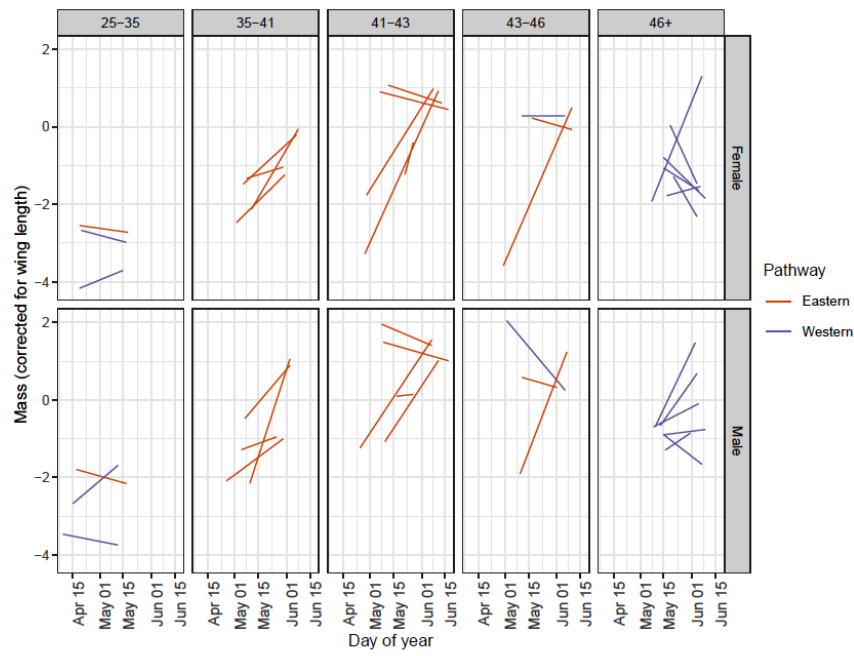

\section{DISCUSSION}

Relatively few studies of the Blackpoll Warbler have focused on spring migration. Our current study brings together multiple years of banding data from across the expansive migratory range of this species to investigate spring migration timing and strategies. With data from over 12,000 Blackpoll Warblers we demonstrate differences in migration patterns between eastern and western 
populations, protandry and differences in the speed of migration between the sexes, and advancement of spring migration timing over the studied 58 years.

Blackpoll Warblers migrated earlier at a rate of 0.5 days per decade over the almost 60 years of our spring migration study. The observed earlier migration was consistent across different times of the migratory period (early, median, and late) indicating that the entire spring migratory season is shifting slightly earlier. Although this advancement of migration timing was not a priori expected because Blackpoll Warblers typically migrate later than other parulid migrants (Rodewald 2015), it is consistent with the findings of previous studies on other migratory bird species (Butler 2003, Moore et al. 2005, Van Buskirk et al. 2009, Covino et al. 2020). Fall migration for Blackpoll Warblers has been occurring later at a rate of approximately 1 day per decade (Morris et al. 2016), which combined with the earlier spring migration provides the possibility of a longer breeding season in this species. Although double brooding is not common among Blackpoll Warblers (DeLuca et al. 2013), a longer breeding season could provide opportunities to renest if initial nesting attempts are not successful.

Our data support our expectation of differences in migration strategies between individuals captured at eastern and western sites. Blackpoll Warblers migrated through western sites earlier than those migrating through eastern sites at similar distances from the wintering grounds. This timing difference between eastern and western pathways were consistent among males and females; therefore, sex-related differences in migratory patterns are not responsible for the variation in migratory strategies (timing and speed) between eastern and western sites. The result suggests that birds from more westerly populations initiate migration earlier than those from eastern populations, which is consistent with the earlier departure of western Blackpoll Warblers from wintering grounds documented by DeLuca et al. (2019).

Patterns of energetic condition were similar for eastern and western birds despite the difference in migration distance; after accounting for size, mass was lowest at southernmost sites, highest at midlatitude sites, and near the expected breeding mass at the most distant sites. This finding, coupled with the increased pace of migration toward the end of migration at western sites (Fig. 2) suggests that western populations exhibit a different migration strategy compared to their eastern counterparts (Fig. 2; DeLuca et al. 2013, 2019). The similar pace of migration exhibited by eastern and western birds for the first three weeks of migration, followed by the striking differences observed in the last week, coupled with the fact that birds in the midwest are at their heaviest during midmigration suggests that western individuals likely stop over in the midwest to refuel prior to making rapid long-distance flights to the breeding grounds. The slightly earlier arrival of birds at western sites in the far south (4 days), and the observation that most of these birds are very low weight, also hints that individuals may be making long-distance flights from wintering areas in South America direct to midwest stopover/refueling sites (e.g., see DeLuca et al. 2019).

Wing length data from eastern and western migratory sites also reflect differences in the migratory patterns between eastern and western breeders. The longer wing lengths at higher latitudes across western sites reflects the longer distance traveled by most northern breeders, which is similar to previous studies showing longer distance migrants have longer wings than shorter distance migrants (e.g. Mönkkönen 1995, Lockwood et al. 1998, Voelker 2001, Vágási et al. 2016). At both eastern and western sites, earlier migrants had longer wings than later migrants, which is potentially driven by known age-related differences in both wing length (adults longer than young, e.g., Pyle 1997) and spring passage date in songbirds (adults earlier than young; e.g., Francis and Cooke 1986, Newton 2008). At southern latitudes wing lengths were similar between eastern and western sites, but wing lengths were longer at the more northern of the western sites compared to eastern sites at similar latitudes (Fig. 3). This finding, along with DeLuca et al. (2019) demonstrates that both eastern and western populations of Blackpoll Warblers are sympatric at some southern latitude stopover sites but that they diverge as they migrate north.

Our data demonstrated protandry, the earlier migration of males than females, and a difference in the migration strategy between the sexes. Protandry is consistent with previous studies of this species (e.g., Eliason 1986) and is widespread among songbirds specifically and migratory birds in general (see Morbey and Ydenberg 2001 for review). We also found evidence for sex-based differences in migration strategy as demonstrated both through differences in energetic condition and through patterns of capture dates. Males were in better energetic condition than females, after accounting for differences in size, which was contrary to the pattern found in a prior study of 12 warbler species, including Blackpoll Warblers (Holzschuh and Deutschlander 2016). Our finding that males arrive consistently earlier and are in better condition than females may be reflective of their boreal breeding range and unpredictability of resources at breeding sites in spring, providing males with insurance for their early arrival (Sandberg and Moore 1996). Although males consistently preceded females both across the geographic range and throughout the migratory period, the difference between capture dates of males and females decreased over the migratory season; there was a greater temporal difference between the sexes among early migrants compared to later migrants. Thus, female Blackpoll Warblers appear to be migrating more quickly than males, which is contrary to previous studies of other migrant songbird species (e.g., Ellegren 1990, Dierschke et al. 2005, Tøttrup and Thorup 2008). The combination of energetic condition and timing differences between the sexes may optimize breeding season activities and indicate constraints in this boreal species.

Because of their extensive range through the boreal forests of North America, and their known extraordinary migratory ability, examining patterns of migratory movement of Blackpoll Warblers in the spring are required for a clear understanding of their annual cycle. Although previous studies have not found evidence of genetic differences between eastern and western Blackpoll Warblers (Ralston and Kirchman 2013, Ralston et al. 2019), there do appear to be differences in migratory routes and strategies between eastern and western populations (DeLuca et al. 2019; this study). Although we found no differences in energetic condition between eastern and western populations, western Blackpoll Warblers depart the wintering grounds earlier (DeLuca et al. 2019) and migrate earlier and more quickly than their eastern counterparts (this study). As a result and despite the longer 
Avian Conservation and Ecology 15(1): 17 http://www.ace-eco.org/vol15/iss1/art17/

distance traveled by western individuals, Blackpoll Warblers from across the range are relatively synchronous in their breeding ground arrival date (DeLuca et al. 2019). This difference in migration strategy thus compensates for the longer migration undertaken by western Blackpoll Warblers. Further, DeLuca et al. (2019) provide evidence that the spring migration is substantially shorter than the southward migration during the fall, suggesting a spring strategy that maximizes migration speed.

The differences between eastern and western populations and between spring and fall migratory seasons, coupled with the evidence we present for important stopover (particularly in the U.S. midwest), demonstrate the importance of detailed and longterm studies throughout the geographic range and the annual cycle. We suggest that such studies focus on delineating the geographic location of these stopover regions, the habitats used by individuals when passing through them, and the rates of fuel deposition. Furthermore, the broad-scale geographic differences we observe (eastern versus western) suggest that conservation actions my need to differ regionally, even without evidence for genetic differences between these groups. These results contribute to the growing body of knowledge of this quintessential migrant, which may be useful for its long-term conservation and survival.

Responses to this article can be read online at: http://www.ace-eco.org/issues/responses.php/1577

\section{Acknowledgments:}

We would like to thank the banding staff and volunteers from all of the banding stations that collected the data for this project including: Alaska Bird Observatory; Appledore Island Migration Station; Atlantic Bird Observatory; Bernard Fashingbauer Banding Operations; Birdsville; Black Swamp Bird Observatory; Block Island Banding Station; Braddock Bay Bird Observatory; Cape Florida Banding Station; Delta Marsh Bird Observatory; First Landing State Park; Foreman's Branch Bird Observatory; Great Gull Island; Island Beach State Park; Lesser Slave Lake Bird Observatory; Long Point Bird Observatory; Louisiana Gulf Coast; Manomet Bird Observatory; Mississippi Barrier Islands; Monitoring Avian Productivity and Survivorship (MAPS) program, a program of The Institute for Bird Populations (IBP); Patuxent Wildlife Research Center Migration Station; Potomac River National Wildlife Refuge; Powdermill Bird Observatory; Presque Isle State Park; Seaside Park; South Dakota Game, Fish and Parks; and Thunder Cape Bird Observatory. In addition, we would like the following people for providing us with the detailed banding records required for our analyses: Michele Davis, Joseph DiCostanzo, Mary Doscher, Jerry Farrell, Bob Fashingbauer, Kim Gaffett, Maren Gimpel, James Gruber, Helen Hayes, Morelle H. Herzinger, Sandy Herzinger, Edwin A. Hicks, Trevor Lloyd-Evans, Mary Messerli, Patricia V. Melville, Frank Moore and the Migratory Bird Research Group, Mabel Ott, Andrea Patterson, Robert Paxton, Bob Reilly, Sarah Sargent, Eileen Stukel, Dan Tallman, and R. P. Yunick. Partial funding for this project was provided by an anonymous donor to the Canisius College Laboratory of Avian Biology. We would also like to acknowledge the support of the NSERC Discovery grants to PDT.
}

\section{LITERATURE CITED}

Bates, D., M. Maechler, B. Bolker, and S. Walker. 2014. Ime4: Linear mixed-effects models using 'Eigen' and S4. R package version 1.1-7. [online] URL: http://cran.r-project.org/package $=$ lme4

Bonter, D. N., T. M. Donovan, and E. W. Brooks. 2007. Daily mass changes in landbirds during migration stopover on the south shore of Lake Ontario. Auk 124:122-133. https://doi.org/10.1093/ auk/124.1.122

Butler, C. J. 2003. The disproportionate effect of global warming on the arrival dates of short-distance migratory birds in North America. Ibis 145:484-495. https://doi.org/10.1046/

j.1474-919X.2003.00193.x

Covino, K. M., K. G. Horton, and S. R. Morris. 2020. Seasonally specific changes in migration phenology across 50 years in the Black-throated Blue Warbler. Auk 137(2). https://doi. org/10.1093/auk/ukz080

DeLuca, W., R. Holberton, P. D. Hunt, and B. C. Eliason. 2013. Blackpoll Warbler (Setophaga striata), version 2.0. In A. Poole, editor. Birds of North America online. Cornell Lab of Ornithology, Ithaca, New York, USA. https://doi.org/10.2173/bna.bkpwar.02

DeLuca, W. V., B. K. Woodworth, S. A. Mackenzie, A. E. M. Newman, H. A. Cooke, L. M. Phillips, N. E. Freeman, A. O. Sutton, L. Tauzer, C. McIntyre, et al. 2019. A boreal songbird's $20,000 \mathrm{~km}$ migration across North America and the Atlantic Ocean. Ecology 100:e02651. https://doi.org/10.1002/ecy.2651

DeLuca, W. V., B. K. Woodworth, C. C. Rimmer, P. P. Marra, P. D. Taylor, K. P. McFarland, S. A. Mackenzie, and D. R. Norris. 2015. Transoceanic migration by a $12 \mathrm{~g}$ songbird. Biology Letters 11(4). https://doi.org/10.1098/rsbl.2014.1045

Dierschke, V., B. Mendel, and H. Schmaljohann. 2005. Differential timing of spring migration in Northern Wheatears Oenanthe oenanthe: hurried males or weak females? Behavioral Ecology and Sociobiology 57:470-480. https://doi.org/10.1007/ s00265-004-0872-8

Dunn, E. H. 2002. A cross-Canada comparison of mass change in birds during migration stopover. Wilson Journal of Ornithology 114:368-379. https://doi.org/10.1676/0043-5643(2002)114[0368: ACCCOM]2.0.CO;2

Eliason, B. C. 1986. Mating system, parental care, and reproductive success in the Blackpoll Warbler (Dendroica striata). Dissertation. University of Minnesota, Twin Cities, Minnesota, USA.

Ellegren, H. 1990. Autumn migration speed in Scandinavian Bluethroats Luscinia s. svecica. Ringing \& Migration 11:121-131. https://doi.org/10.1080/03078698.1990.9673974

Francis, C. M., and F. Cooke. 1986. Differential timing of spring migration in Wood Warblers (Parulinae). Auk 103:548-556. https://doi.org/10.1093/auk/103.3.548

Holberton, R. L., S. L. Van Wilgenburg, A. J. Leppold, and K. A. Hobson. 2015. Isotopic ( $\delta 2 \mathrm{Hf}$ ) evidence of "loop migration" and use of the Gulf of Maine Flyway by both western and eastern breeding populations of Blackpoll Warblers. Journal of Field Ornithology 86:213-228. https://doi.org/10.1111/jofo.12112 
Holzschuh, J. A., and M. E. Deutschlander. 2016. Do migratory warblers carry excess fuel reserves during migration for insurance or for breeding purposes? Auk 133:459-469. https://doi. org/10.1642/auk-15-141.1

Lockwood, R., J. P. Swaddle, and J. M. V. Rayner. 1998. Avian wingtip shape reconsidered: wingtip shape indices and morphological adaptations to migration. Journal of Avian Biology 29:273-292. https://doi.org/10.2307/3677110

Mönkkönen, M. 1995. Do migrant birds have more pointed wings?: A comparative study. Evolutionary Ecology 9:520-528. https://doi.org/10.1007/BF01237833

Moore, F. R., R. J. Smith, and R. Sandberg. 2005. Stopover ecology of intercontinental migrants. Pages 251-261 in $\mathrm{R}$. Greenberg and P. P. Marra, editors. Birds of two worlds: the ecology and evolution of migration. Johns Hopkins University Press, Baltimore, Maryland, USA.

Morbey, Y. E., and R. C. Ydenberg. 2001. Protandrous arrival timing to breeding areas: a review. Ecology Letters 4:663-673. https://doi.org/10.1046/j.1461-0248.2001.00265.x

Morris, S. R., K. M. Covino, J. D. Jacobs, and P. D. Taylor. 2016. Fall migratory patterns of the Blackpoll Warbler at a continental scale. Auk 133:41-51. https://doi.org/10.1642/AUK-15-133.1

Morris, S. R., M. E. Richmond, and D. W. Holmes. 1994. Patterns of stopover by warblers during spring and fall migration on Appledore Island, Maine. Wilson Bulletin 106:703-718.

Newton, I. 2008. The migration ecology of birds. Academic, London, UK.

Nisbet, I. C. T. 1970. Autumn migration of the Blackpoll Warbler: evidence for long flight provided by regional survey. Bird Banding 41:207-240. https://doi.org/10.2307/4511673

Pyle, P. 1997. Identification guide to North American birds: Part 1. Braun-Brumfield Inc., Ann Arbor, Michigan, USA.

Pyle, P., S. N. G. Howell, R. P. Yunick, and D. F. Desante. 1987. Identification guide to North American passerines. Slate Creek, Bolinas, California, USA.

Ralston, J., and J. J. Kirchman. 2013. Predicted range shifts in North American boreal forest birds and the effect of climate change on genetic diversity in Blackpoll Warblers (Setophaga striata). Conservation Genetics 14:543-555. https://doi.org/10.1007/ s10592-012-0418-y

Ralston, J., L. Lorenc, M. Montes, W. V. DeLuca, J. J. Kirchman, B. K. Woodworth, S. A. Mackenzie, A. Newman, H. A. Cooke, N. E. Freeman, et al. 2019. Length polymorphisms at two candidate genes explain variation of migratory behaviors in Blackpoll Warblers (Setophaga striata). Ecology and Evolution 9:8840-8855. https://doi.org/10.1002/ece3.5436
Rodewald, P. G., editor. 2015. The birds of North America. Cornell Lab of Ornithology, Ithaca, New York, USA.

Rosenberg, K. V., J. A. Kennedy, R. Dettmers, R. P. Ford, D. Reynolds, J. D. Alexander, C. J. Beardmore, P. J. Blancher, R. E. Bogart, G. S. Butcher, et al. 2016. Partners in Flight landbird conservation plan: 2016. Revision for Canada and Continental United States. Partners in Flight Science Committee. [online] URL: https://partnersinflight.org/wp-content/uploads/2016/08/ pif-continental-plan-final-spread-single.pdf

Sandberg, R., and F. R. Moore. 1996. Fat stores and arrival on the breeding grounds: reproductive consequences migrants for passerine migrants. Oikos 77:577-581. https://doi.org/10.2307/3545949

Tøttrup, A. P., and K. Thorup. 2008. Sex-differentiated migration patterns, protandry and phenology in North European songbird populations. Journal of Ornithology 149:161-167. https://doi. org/10.1007/s10336-007-0254-X

United States Fish and Wildlife Service and Canadian Wildlife Service. 1977. Bird banding manual Volume II: bird banding techniques. United States Fish and Wildlife Service, Washington, D.C., USA and Canadian Wildlife Service, Ottawa, Ontario, Canada.

Vágási, C. I., P. L. Pap, O. Vincze, G. Osváth, J. Erritzøe, and A. P. Møller. 2016. Morphological adaptations to migration in birds. Evolutionary Biology 43:48-59. https://doi.org/10.1007/s11692-015-9349-0

Van Buskirk, J., R. S. Mulvihill, and R. C. Leberman. 2009. Variable shifts in spring and autumn migration phenology in North American songbirds associated with climate change. Global Change Biology 15:760-771. https://doi.org/10.1111/ j.1365-2486.2008.01751.x

Voelker, G. 2001. Morphological correlates of migratory distance and flight display in the avian genus Anthus. Biological Journal of the Linnean Society 73:425-435. https://doi.org/10.1111/ j.1095-8312.2001.tb01371.x

Williams, T. C., and J. M. Williams. 1978. An oceanic mass migration of land birds. Scientific American 239:166-176. https:// doi.org/10.1038/scientificamerican1078-166

Wood, M. 1969. A bird-bander's guide to determination of age and sex of selected species. College of Agriculture, The Pennsylvania State University, University Park, Pennsylvania, USA.
Editor-in-Chief: Keith A.Hobson Subject Editor: Nicholas JBayly
Sponsored by the Society of Canadian Ornithologists and Birds Canada Parrainée par la Société des ornithologistes du Canada et Oiseaux Canada

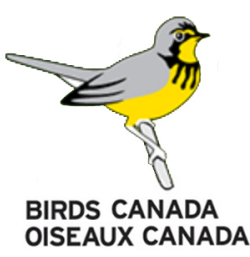


Appendix 1. Capture date for Blackpoll Warblers (Setophaga striata) by sex and site (latitude-longitude bin, see methods) throughout spring migration. Points are mean date of capture for each year at each site, black vertical line represents the grand mean across years at each site, and the size of each point is the relative number of individuals captured in that year.

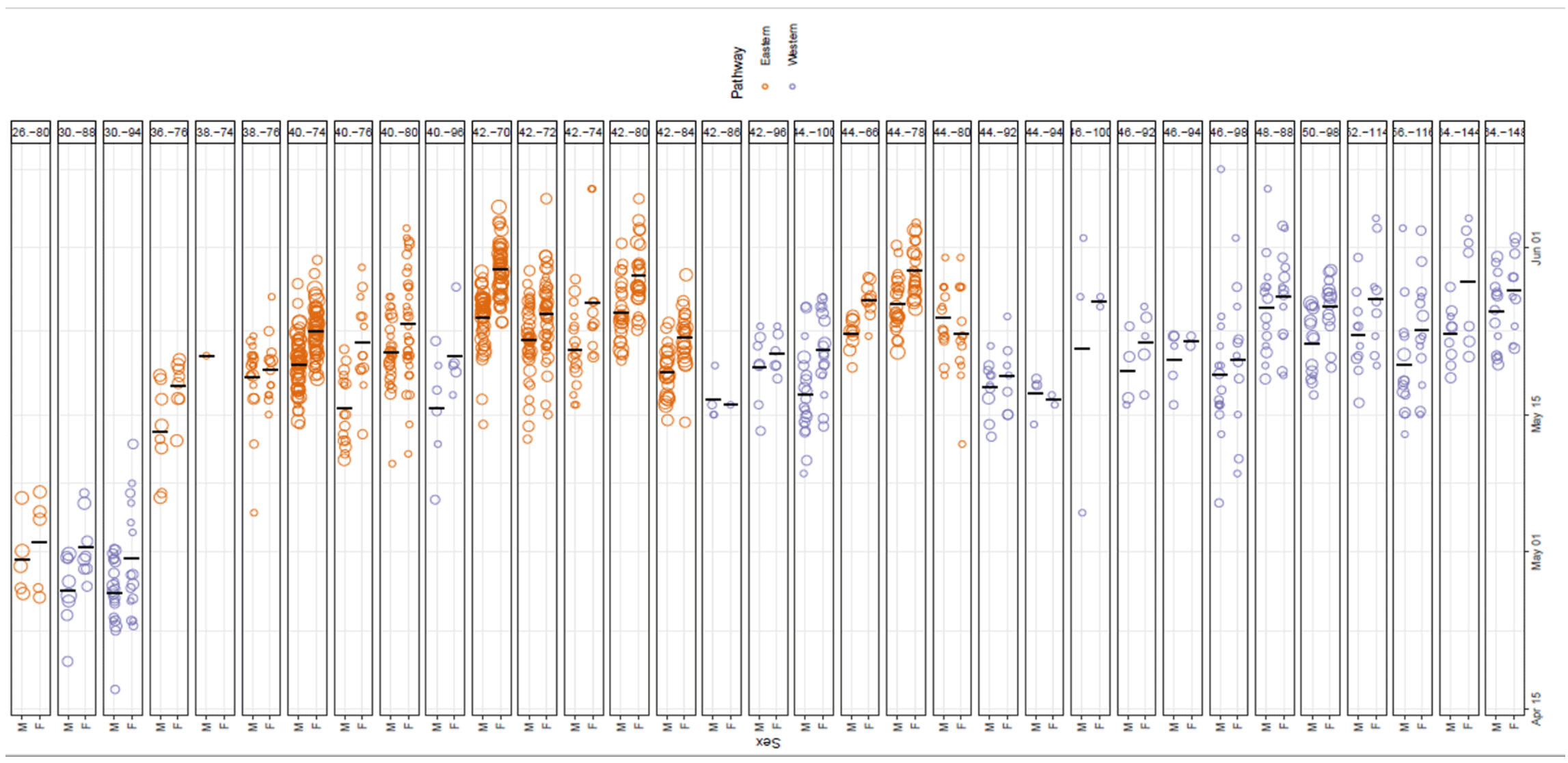


